
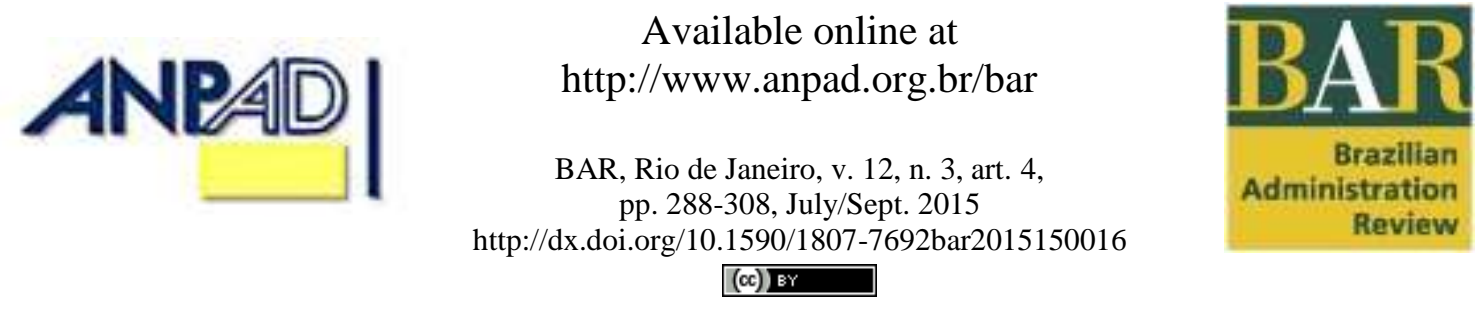

Administration

Review

(c) $\mathbf{E Y}$

\title{
Environmental Management, Strategic Practices and Praxis: A Study in Santa Catarina Industrial Companies
}

\author{
Graziela Dias Alperstedt \\ Universidade do Estado de Santa Catarina - UDESC/ESAG \\ Sergio Bulgacov \\ Fundação Getulio Vargas - FGV/EAESP
}

Received 21 April 2015; received in revised form 14 August 2015; accepted 2nd September 2015; published online 30 September 2015. 


\begin{abstract}
This article analyzed the correlation between strategic praxis related to environmental management in Santa Catarina industrial companies and their strategic practices. This quantitative study is based on the theoretical foundations of environmental management and strategy as practice. Praxis (environmental management) is understood as a cluster of three perspectives: product design, main processes and support system. The data were collected by way of an online questionnaire, with 225 completed and submitted to canonical correlation multivariate analysis using SPSS software, confirming the hypothesis that there is a correlation between companies' praxis (environmental management) and strategic practices. However, the correlation best represents the original variables at the support system level, seeking to value the correlation. Likewise, not all original variables make up the new canonical variable, which suggests that there are new implications.
\end{abstract}

Key words: environmental management; strategic practices; strategic praxis; canonical correlation; industrial companies. 


\section{Introduction}

In recent years, the number of studies that analyze the relationship between companies and the natural environment has grown. This is because global environmental problems, such as climate change, have raised the awareness of society in general concerning the impact of business activities on planet's sustainability (Aragòn-Correa, Hurtado-Torres, Sharma, \& Garcia-Morales, 2008; Brown, Vergragt, \& Cohen, 2013; Yang, Yang, \& Peng, 2011). The challenge of sustainability transcends technological advancement. This also includes a change in societal values in addition to the restructuring of public and economic institutions. In this sense, not only the innovations in industrial production are necessary, but also innovations in a company's consumption patterns (Brown et al., 2013).

According to Newton and Harte (1997), many researchers are concerned over the difficulty of making real improvements to the environment, since the social paradigms and normative structures that guide decision making in this field have remained. There is also a group of scholars who have found that the natural environment has been used by managers more for strategic purposes than for ethical or normative reasons (Aragón-Correa, Matías-Reche, \& Senise-Barrio, 2004; Banerjee, 2001; Cordano \& Frieze, 2000; Sharma, 2000).

Actually, companies' environmental management can be seen as the result of strategic practices regarding the natural environment, often based on managers' perceptions regarding the importance given to the environment and the many external restrictions that are imposed (Coyle, Thomchick, \& Ruamssok, 2015; Reis \& Queiroz, 2002). Considered a managerial function, environmental management is responsible for the implementation of strategic environmental policies that are implemented by businesses. However, these policies and practices are not always transformed into praxis, leading back to the old problem of the separation of thought and action.

Although organizations have voiced their concern over the construction and maintenance of cleaner and more ecologically sustainable systems (strategic practices), concerns remain over the effectiveness of the environmental management systems put in place by companies (strategic praxis). After all, does praxis related to environmental management systems in companies correspond to their strategic practices?

To ponder this question, this study is based on the perspective of strategy as practice, considering strategy as a social practice (Whittington, 1996). Here, practices are related to "cognitive, behavioral, procedural, discursive, motivational and physical resources that are combined, coordinated and adapted to construct practice" (Seidl \& Vaara, 2010, p. 11). Nevertheless, the discourse of strategy in this case does not refer only to the idiosyncratic product of a certain corporate culture, but as part of a considerable social change with effects that reach far beyond the organization. Strategy in this case is viewed as a social phenomenon that alters managers' self-understanding in general.

This study is justified by the gaps in studies on environmental management in business through the perspective of strategy as practice and the lack of studies on the theme in companies in emerging countries. In general, the dominant theory is generated in the context of developed countries, suggesting that studies should be conducted to confirm whether the mainstream is applicable to the context of emerging countries, given the considerable differences between countries (Kang, 2011).

Regarding this issue in particular, numerous studies have documented the weak institutional pressure of many developing countries in terms of environmental regulations and norms. They have reported the difficulties that companies in some countries face to access technology and the skills necessary for environmental proactivity. This has resulted in certain locations coming to be seen as pollution paradises (Christmann \& Taylor, 2001). In Brazil's case, the adoption of sustainable practices is still low despite the existence of laws, because there is inadequate supervision to ensure that organizations are respecting the environment (Bonilla, Almeida, Giannetti, \& Huisingh, 2010). 
On the other hand, as suggested by Peng, Wang and Jiang (2008), institutional forces play a central role in the formation of business strategies in emerging countries due to the strong legacy of government or political involvement in business affairs (Kang, 2011).

Considering that strategic practices do not always correspond to praxis, this study aims to empirically analyze the correlation between strategic practices and praxis in relation to Santa Catarina businesses' environmental management systems. Therefore, the proposed hypothesis is that there is correlation between strategic practices and praxis in relation to the environmental management systems of Santa Catarina industrial companies.

\section{Environment, Companies and Environmental Management}

In recent years, society has become increasingly aware of the importance of protecting the environment and the planet's natural ecology (Bonilla et al., 2010; Kanji, 2008; Pedroso, Cella-deOliveira, Dutra, \& Morozini, 2012; Surjono, 2011). This has resulted in tougher environmental standards for the business community. A number of mechanisms such as the ISO 14000 environmental management certification have institutionalized international standards and put pressure on industry to improve environmental practices (Yang et al., 2011).

Recognition of these environmental demands has led to changes in the lifecycle and in production costs (to eliminate the residuals and adopt adequate control processes). Alfred and Adam (2009) realized that environmental management is positively associated with companies' operating performance, as it increases the relative productivity of inputs, reduces production costs and maximizes the use of organizational resources. Growing regulatory pressure and client's environmental requirements have also forced industry to reduce or even eliminate the adverse environmental impacts of products and processes. Therefore, environmental management, which includes all efforts to minimize the environmental impacts of a company's processes and products throughout their lifecycle (Klassen \& Mclaughlin, 1996), has become an extremely important function in almost every type of industry. "There is also a growing conviction that environmental sustainability challenges require actions that directly impact business strategies and supply chain practices" (Coyle et al., 2015, p. 365). In this sense, sustainable practices can generate new opportunities and, consequently, transform organizations (PerezValls, Cespedes-Lorente, \& Moreno-Garcia, 2015).

Pollution is the main challenge for environmental management (Yang et al., 2011) and can be considered a form of residual (Porter \& Van Der Linde, 1995), as it consumes resources and increases costs with no compensation at all (Handfield, Walton, Sroufe, \& Melnyk, 2002). As a result, organizations have made efforts to develop products and services that reduce pollution, require less packaging and less energy consumption (Humphreys, Wong, \& Chan, 2003). With this need in mind, the environmental issue has become part of strategic planning in many companies (Donnelly, BeckettFurnell, Traeger, Okrasinski, \& Holman, 2006; Maas, Schulster, \& Hartmann, 2014), which seek alternatives to minimize the adverse environmental impacts of their activities during their products lifecycles (Alfred \& Adam, 2009; Sroufe, Montabon, Narasimhan, \& Wang, 2002).

As the production of green products is manufacturers' responsibility, companies have been concerned with reducing the use of energy and resources, eliminating toxicity from their raw materials and looking at ways of recycling and reusing products at the end of their lifecycles (Gerner, Kobeissi, David, Binder, \& Descotes-Genon, 2005).

A number of countries require manufacturers to accept the return of their products after they have been used by consumers. This encourages industry to design products that can easily be recycled or reused. In this way, a green global strategy combines the functions of design, purchase, production, management of suppliers, logistics (including reverse logistics) and information management (Shih, 
2003). Therefore, to improve environmental management, companies need to pay attention to the whole production process, including design, raw materials, manufacture, use and recycling.

Performance is measured in terms of positive or negative effects on the natural environment. Manufacturer's operations and products (James, 1994) cause these effects. Nevertheless, despite recognizing the growing importance of environmental management in manufacturing processes throughout the lifecycle of a product, there is a problem concerning how to make decisions about main activities to achieve adequate environmental management in companies.

Selecting the right tool to implement environmental management is very important in terms of costs and compliance with stakeholders' regulatory requirements (Montabon, Sroufe, \& Narasimhan, 2007). Humphreys, Wong and Chan (2003) suggested that attention should be paid to five aspects of environmental management: (a) management decisions, (b) green image, (c) environmental design, (d) environmental management system, and (e) environmental competences.

According to Yang, Yang and Peng (2011), the many aspects of environmental management can be implemented through performance criteria and their respective related operations. According to these authors, based on the provisions of international environmental management system ISO 14031, Kolk and Mauser (2002) used three elements to measure environmental management: (a) environmental management indicators, (b) environmental condition indicators; and (c) environmental performance indicators. The latter was subdivided into several operational indicators, such as acquisition, production process, and use and disposal of products. Through these evaluation criteria, the critical practices required for environmental management can be selected and adopted.

Porter's value chain was used in the development of the model by Yang et al. (2011), who proposed the systematic environmental management adopted in this work, consisting of three major perspectives: (a) conception of the product, (b) the main processes, and (c) the support functions. The relative praxis of environmental management has to do with the processes and support functions, borrowed from Porter's model (1985) and based on Porter and Van der Linde (1995) hypothesis that being green is being competitive. In addition to these two perspectives, the model proposed by the authors also includes product design, since the potential for recycling and reduced residuals is essentially determined during the conception phase. Product conception includes the design of green products, their components and processes. During the design development stage, the designers need to consider the green provisions and requirements and ensure that the materials, components and manufacturing process comply with them. Likewise, packaging has to be developed that can be recycled and reused, and also reduced and returned as much as possible. The applications of reverse logistics systems should also be enabled. The main processes include quality control of raw materials, monitoring and isolation, reduced use of resources and energy, including reduced emission, quality control and the management of green materials and harmful substances during storage. The support systems include environmental management mechanisms, including placing someone in charge of this area of the company and the maintenance and calibration of machinery, education and training of employees concerning environmental issues, compliance with legislation and legal environmental requirements and the green image.

Hart (1995), using a Natural-Resource-Based View, argues that there are three strategic courses that can be developed by companies: pollution prevention, product stewardship and sustainable development. Each of these has different driving forces and is based on diverse key resources. Pollution prevention seeks to prevent the production of residuals and emissions rather than clean them up after production. This results in lower costs. For example, removing pollutants before the production process can increase efficiency through (a) fewer necessary inputs, (b) simplified processes, and (c) lower costs and fulfilled responsibility. Product stewardship broadens the scope of pollution prevention to include the entire value chain or the lifespan of a company's products. With the involvement of interested parties, the voice of the environment can be effectively integrated with the product development project (Hart \& Dowell, 2011). Finally, sustainable development is different from pollution prevention and product stewardship in two notable ways. First of all, a sustainable development strategy seeks not only to curtail environmental damage but also to produce a way of truly avoiding such damage 
indefinitely in the future. Secondly, sustainable development, as its name suggests, is not restricted to just environmental concerns, but also to social and economic issues. As economic activity in developed countries is closely linked to issues of poverty and degradation, a strategy with sustainable development has to recognize this link and act to reduce the environmental impact and increase economic benefits for less developed markets affected by the company's activities (Hart \& Dowell, 2011).

As seen in the considerations voiced so far, environmental management can be considered a set of directives for management activities with a view to obtaining positive results in relation to the environment, reducing or eliminating the environmental damage caused by a company (Barbieri, 2006). Uehara, Otero, Martins, Philippi and Mantovani (2010) highlight the plural role of environmental management as an instrument for regulating the relationship between society and nature, influencing business practices and reflecting on a company's mission and values.

In general, considerations on the environmental aspects of business strategy have formed a new business paradigm, unveiling benefits that had not been perceived by the business world, such as improving organizations' images, opening up new markets, improving production processes, realizing savings on raw materials, increasing income and reducing waste. Environmental aspects also benefit products, both in terms of improved quality and lower packaging costs (Hrdlicka, 2009).

The next topic explores strategic practices and praxis to understand the formal and informal actions of doing strategy concerning environmental management and analyzes the praxis from the Yang et al. (2011) model.

\section{Strategic Practices and Praxis}

The idea of practice is linked to shared behavior routines, such as traditions, norms, ways of thinking and attitudes in a broader sense (Whittington, 2006). When practices have strategic consequences for organizations, such as a competitive advantage, financial results and a better market, they are considered strategic (Johnson, Melin, \& Whittington, 2003), despite their formal planning and articulation (Jarzabkowski, Balogun, \& Seidl, 2007).

Jarzabkowski, Balogun and Seidl (2007) cite practices according to Reckwitz, who views them as "routinized types of behavior which consist of several elements, interconnected to one another: forms of bodily activities, forms of mental activities, 'things' and their use, a background knowledge in the form of understanding, know-how, states of emotion and motivational knowledge" (p. 6). In this sense, practices can also be referred to as cognitive, behavioral, procedural, discursive, motivational and physical. When these are combined, coordinated and adapted, they end up creating a form of praxis (Walter \& Augusto, 2012). These strategic practices can be classified as rational, discursive and episodic. Rational practices are used to organize and coordinate strategy, including planning, budgeting, forecasting, control systems, performance indicators and goals. They are important because they serve as mechanisms that act as a go-between for the action of actors who are striving to achieve their strategic goals. Discursive practices include a range of factors that incorporate the discourse of strategy and the tools and techniques that are translated into everyday language concerning discourse (Jarzabkowski, 2005). Episodic practices provide interaction between practitioners in the formation of strategy and include meetings, seminars and external contacts.

One of the factors for understanding strategic practices is the analysis of managerial policies that are implemented and supported by managers. Strategic practices are constituted through the knowledge of the actors involved in an organization's strategic process and are based on explicit knowledge used for analysis, planning and action to achieve a certain goal (Chia \& Rasche, 2010). In other words, the focus here is on policies and managerial actions and how coherent they are, and what strategists and other managers effectively do with their rational choices. 
Policies, as part of strategic action, are guides for strategic practices implemented over time and spread by personal and organizational values. In this sense, the empirical considerations analyzed in this study include competitors, stakeholders, initiatives connected with government policy on the environment and environmental certifications, the sum of which constitutes what can be referred to as strategic practices. According to Adams, Licht and Sagiv (2011), these practices are constituted by personal values and placed in the daily life of the organization when it is confronted by dilemmas that arise in decision making processes or in relationships with its stakeholders. A point in question is the growing awareness of consumers concerning environmental factors and how these affect their purchase decisions (Kang, 2011). Studies suggest that consumers in industrialized countries have become sharply more aware of environmental issues (Arora \& Cason, 1995; Christmann, 2004; Henriques \& Sadorsky, 1999; Simon, 1992). Therefore, consumer expectations in relation to the environment have become a significant pressure, and the image of companies responsible for pollution has been further tarnished by collective boycotts. In this sense, greater environmental awareness has been observed in consumer behavior (Kang, 2011), and companies have been increasingly aware of this in their strategic practices.

Another source of institutional pressure that has been a concern in the formation of business policies and translated into strategic actions is mimetic pressure, since one of the ways of achieving legitimacy stems from mimetic mechanisms. As a result of ongoing efforts to reduce negative environmental impacts and at the same time improve their competitive advantage, some leading companies have developed environmental management practices (Christmann, 2000; Hart, 1995; Shrivastava, 1995) that end up being adopted by other companies.

Therefore, policies evolve over time through internal and external interactions, both personal and organizational. In other words, a policy is a relevant part of strategy as it characterizes organizational patterns that are set in place over time and lead to strategic operations and guide business decisions and practices.

Taking a broad view of organizational policies, their importance to environment issues is underlined by the fact that environmentalism has been institutionalized in the mainstream of social life since the early 1990s, involving all business functions (Simon, 1992). In this context, companies have to comply with laws and regulations to protect the environment and be isomorphic with practices and patterns of environmental management to gain the legitimacy that is essential for their survival. Governments and social institutions impose regulatory restrictions and offer normative guidelines, supplying companies with mimetic mechanisms (Kang, 2011).

Although different companies have different environmental approaches that range from more passive behavior to more reactive and more proactive behavior, all companies need to comply with the restrictions imposed by legislation and environmental regulations (Kang, 2011). This is the case of Federal Law 12.305, of 02.08.2010 (Lei n. 12.305, 2010), which institutes the National Policy for Solid Residuals and includes reverse logistics. According to this law, responsibility for the generation of residuals, including the dangerous ones, lies with those who produce it and with the government.

On the other hand, the literature and practice show that there are significant differences in the levels of restriction of environmental norms and in the ability to implement, monitor and comply with them in developed and developing countries (Majumdar \& Marcus, 2001; Nehrt, 1998) and in emerging economies (Child \& Tsai, 2005; Hettige, Hug, Pargal, \& Wheeler, 1996).

For this reason it is important for a policy to translate the institutional dimension for the organization, which in turn affects the formation of environmental strategies because therein lie the norms that represent the nature of the reality and the framework through which meanings are constructed by social actors (Scott, 2001). This means that despite the objective conditions, subjective interpretations of the environment will be made and will configure the actions of individuals, valuing the symbols and meanings found in the daily life of the organization.

Strategic practices translate strategy as a flow of socially conducted and located activities, which consequently affect all involved in the organizational process, be they external or internal stakeholders, 
including owners. Agents interacting with each other can be characterized in the terms of Emirbayer and Mische (1998) as a process of temporally immersed social involvement, in which participants, through routine, imagination and judgment, both reproduce and transform organizational routines and practices.

Thus, the practices involved in strategy are considered by Jarzabkowski and Balogun (2009) and Whittington (2003) as the influence of the flow of activities in terms of the actions and policies of the organization. Therefore, as long as they use their influence in the form of demands and expectations, the proprietors and stakeholders can be considered important agents of the context and situation when it comes to the strategic practice. This is because it creates value in a recursive process, such as environmental practices.

Praxis has to do with what is happening in society and what people are actually doing. It includes the connection between the actions of different individuals and groups that are spread socially, politically and economically in institutions where individuals act and make contributions. This definition is important because it shows that praxis is a concept that can be operationalized at different levels, ranging from the micro to the institutional, and that it is dynamic. It can change smoothly through interaction between levels (Jarzabkowski \& Spee, 2009). Therefore, praxis can be understood at a broader social level as the flow or flows of activity in time, while at the micro level it is understood through actions, interactions and negotiations on the part of multiple actors.

Whereas praxis represents what is actually accomplished in an organization, or all the formal and informal actions that go into doing strategy (Jarzabkowski \& Spee, 2009), in this study it is understood as the actions of industry concerning environmental management adapted from the model of Yang et al. (2011).

Based on the discussed theoretical foundations, the next section deals with the methodological procedures used for the purpose of this work.

\section{Methodological Strategy}

This quantitative study was conducted in industrial companies in Santa Catarina, Brazil. In this sense Brazil provides a suitable scenario for studying and discussing the adoption of environmental management strategies in industry, mainly because some literature has claimed that emerging countries are pollution paradises (Acselrad, 2004; Copeland, 2008). The second sector (industry) was chosen because of its impact on and importance to the Brazilian economy and its impact on the environment.

The sample population consisted of companies registered in the databases of the Federation of Industry of Santa Catarina State (FIESC), with a total of 887 industrial plants. The size of each company was gauged by the number of active employees and included large and medium-sized companies.

Data were collected between October 2012 and July 2013. An online questionnaire was forwarded to the people in charge of the companies' environmental sectors. The respondent received a structured Auto-Fill questionnaire. The survey enabled the collection of information from individuals regarding themselves or the organizations in which they work (Forza, 2002). In addition to information about the company profile, a set of questions regarding strategic praxis in environmental management were asked, including question about product design, main processes and support systems, and company policies and respective strategic practices.

Responses were received from 276 industrial plants belonging to 225 companies, with the same person responding for more than one plant in the same company. To avoid data contamination, only one response was considered from each respondent.

For each question, the respondent had to classify the company using a five-point Likert scale. The ordinal criterion for this had been discussed by a group of specialists. In the context of this study, 1 
represents the least involvement with the theme in question and 5 the highest. It was not necessary to standardize the variables as all the variables had the same scale.

The study sought to identify correlations between a set of dependent variables and a second set of independent variables. The set of dependent variables are related to praxis (environmental management), and it is divided into three groups: product design, main processes and support system. The set of independent variables has to do with the companies' strategic practices.

The conceptual model for praxis (environmental management) that forms the basis of the study and the questionnaire were prepared using the requirements of ISO 14001 and the approach proposed by Yang et al. (2011), according to whom environmental management can be viewed as a system composed of three sets of key activities: product design, main processes and support system. This conceptual model, the theoretical framework and the collected data resulted in the model shown in Table 1.

For companies' strategic practices (independent variable), aspects based on the literature on policy and strategic practices discussed in Section Strategic Practices and Praxis of this article and also shown in Table 1 were studied.

Based on a review of the literature and the conceptual model of the study, the following hypothesis was formulated:

H1: There is a correlation between praxis (environmental management) and the strategic practices adopted by companies.

To work on this set of dependent and independent variables the Canonical Correlation Analysis (CC) was tentatively chosen. Of all the multivariate techniques it is the least restrictive for handling the variables of the study (Hair, Black, Babin, Anderson, \& Tatham, 2009). The study deals with praxis (environmental management) and strategic practices based on a set of multiple dependent and independent variables. In this sense, the Canonical Correlation is a multivariate statistical model that enables these interrelations between multiple dependent and independent variables, with fewer restrictions on the types of data on which it operates. Considering that the other techniques impose stricter restrictions, the information obtained from them is believed to be of higher quality and facilitates interpretation. In situations with multiple dependent and independent variables, canonical correlation is the most suitable multivariate technique and has gained wider acceptance due to growing interest in the consideration of multiple variables (Hair et al., 2009).

Canonical Correlation is a measurement of the correlation between two latent variables (canonical functions), which are in turn linear combinations of the original variables. These latent variables are determined for the purpose of maximizing the linear correlation between them.

Thus:

. $\mathrm{FC}_{1}=\mathrm{a}_{1} \mathrm{x}_{1}+\mathrm{a}_{2} \mathrm{x}_{2}+\mathrm{a}_{3} \mathrm{X}_{3}+\ldots . .+\mathrm{a}_{\mathrm{n}} \mathrm{x}_{\mathrm{n}}$

$\mathrm{FC}_{2}=\mathrm{b}_{1} \mathrm{y}_{1}+\mathrm{b}_{2} \mathrm{y}_{2}+\mathrm{b}_{3} \mathrm{y}_{3}+\ldots . .+\mathrm{b}_{\mathrm{k}} \mathrm{y}_{\mathrm{k}}$

Therefore, the correlation $\left(\mathrm{FC}_{1}, \mathrm{FC}_{2}\right)$ is at a maximum when:

. $\mathrm{FC}_{1}$ is the canonical function for the independent variables

- $\mathrm{FC}_{2}$ is the canonical function for the dependent variables

. $\mathrm{x}$ set of independent variables

. y set of dependent variables

. $\quad \mathrm{a}$ and $\mathrm{b}$ are the canonical coefficients 
Several pairs of canonical functions (latent variables) can be created in CC, and for each of them there will be a canonical correlation coefficient $\left(\mathrm{R}_{\mathrm{C}}\right)$ that will be tested to tell whether it is other than zero $\left(\mathrm{H}_{0}: \mathrm{R}_{\mathrm{c}}=0\right)$. The $\mathrm{Rc}$ is the estimate of the shared variance through the linear combination of the dependent and independent variables (canonical functions). The rejection of $\mathrm{H}_{0}$ tells us that there is a relationship between the groups of variables and for this the Wilk's Lambda multivariate test is used. If the level of significance is found to be lower than $5 \%(\mathrm{p}<0.05)$, then $\mathrm{H}_{0}$ is rejected.

In addition to evaluating the $\mathrm{Rc}$ - canonical correlation of the canonical function that evaluates whether there is a canonical correlation of the dependent and independent variables. It is also necessary to evaluate the contribution of the latent variables' existing relationships. Sometimes, even with a low statistical contribution, these relationships can be helpful regarding discoveries that aid understanding of the theme in question.

Another important indication in the determination of the number of canonical functions to be considered is the Redundancy Index, which is the estimate of the variance shared by the linear combination of dependent and independent variables (canonical functions). In this sense, the higher the index, the better the set of original variables, both dependent and independent, is represented.

There are no rules for the acceptance of an index. Normally, an index with values lower than 0.30 suggests a weak representation of the original variables and the interpretations of latent variables can be affected and/or mistaken.

The interpretation of the canonical functions has to be done evaluating the weights (canonical loadings) attributed to each variable and also by the cross-loadings (correlation of the variable with the canonical function). The higher these values are, the greater the strength of the original variable in the canonical function. Squared cross-loadings show how much the variability of the variable is being represented in the canonical function. For this reason, only loadings higher than 0.30 (minimum acceptable limit) were considered.

\section{Analysis of the Results}

To verify the hypothesis, the canonical considerations with the different sets of variables were run with the aid of the SPSS, as summarized in Table 1:

Table 1

Summary of the Set of Dependent and Independent Variables

\begin{tabular}{l} 
SETS OF DEPENDENT VARIABLES $($ DV $):$ \\
\hline VD: $\quad$ STRATEGIC PRAXIS \\
\hline DV1: Product Design \\
\hline Product designs and green processes \\
Package design and reverse logistics \\
\hline
\end{tabular}

Continues 


\section{Table 1 (continued)}

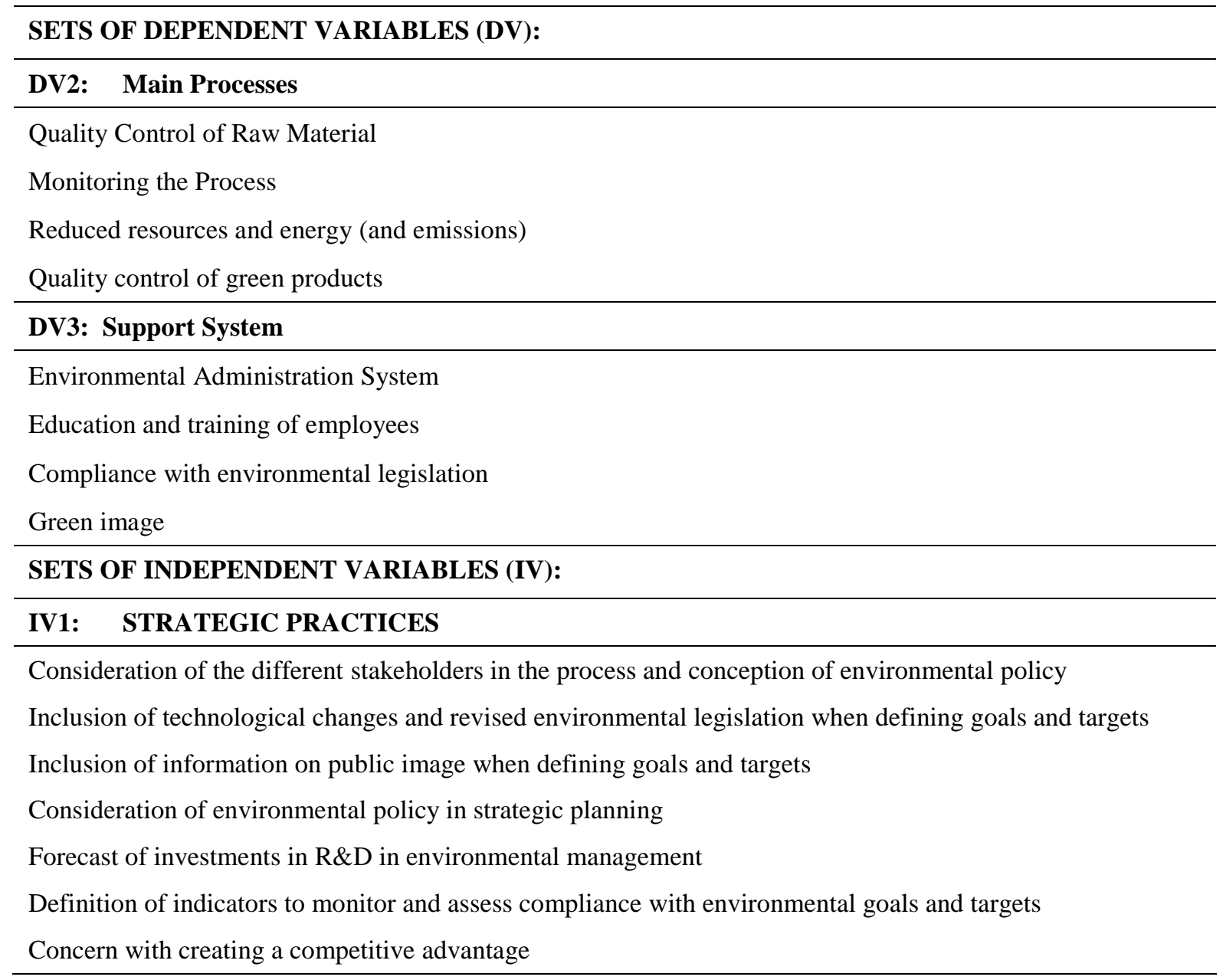

For a better understanding of the correlations between the dependent and independent variables, it was decided that the three sets of dependent variables (DV1, DV2 and DV3) would be studied separately. At this stage it was possible to identify the set of variables that best explains the praxis and strategic practice dimensions. When the CF (canonical function) did not explain the variable well, it was not considered in the interpretation.

\section{Testing the hypothesis}

To test the hypothesis of a correlation of the levels of environmental management (praxis) with the strategic practices adopted by companies (H1), a table was constructed with the main results of the canonical functions that were found, such as the number of functions, the canonical correlation of each of them, the significance (p) given by the Wilk's Lambda statistic and the Redundancy Index (RedInd) of the set of dependent and independent variables.

Using the canonical correlation technique, a correlation was found between the subsets of the Praxis (Environmental management) variables and the subset of variables for the Strategic Practices adopted by the companies, thus confirming $\mathrm{H} 1$.

However, the most expressive canonical correlations for Strategic Practices were found when evaluated with the subsets of dependent variables related to the Main Process (DV_2)' and the 'Support System (DV_3)'. Four and five latent variables (canonical functions), respectively, were detected, with statistical significance $(\mathrm{p}<0.05)$ as shown by the Wilk's Lambda test in Table 2, although only the first 
canonical function of each of the groups should be considered, since only it had an acceptable Redundancy Index for the set of dependent variables (Y).

Table 2

Canonical Functions, Canonical Correlation, Significance, Wilk's Lambda and Redundancy Index (RedInd) of the Set of Dependent and Independent Variables

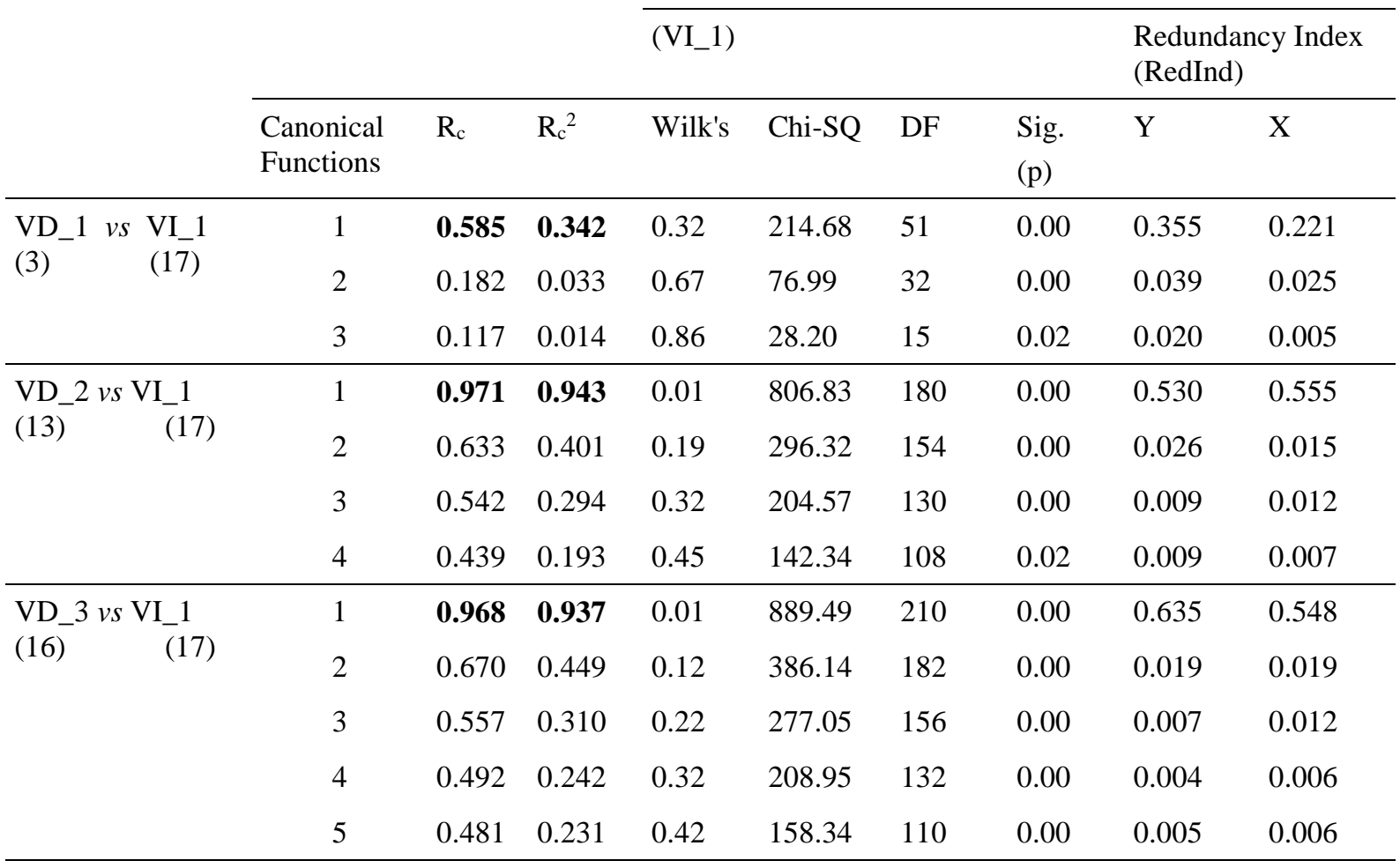

For the Main Process and Strategic Practices an $R_{c}=0.971$ was obtained, with a redundancy index of RedInd $(Y)=0.530$, and for Support system and Strategic Practices an $R_{c}=0.968$ and RedInd $=0.635$. For Product Design and Strategic Practices the correlation, although significant, is much lower, with $\mathrm{R}_{\mathrm{c}}=0.585$ and RedInd $=0.355$.

The Redundancy Index (Y) for Support System and Strategic Practices is slightly higher than that of Main Process and Strategic Practices and, considering that the Rc of both evaluations are very close, it could be said that the latent variable found for the first group (Support System and Strategic Practices) represents the original variables better and, consequently, helps to value the correlation that was found. Thus, the analysis of the study's findings concentrates more heavily on this correlation.

\section{Analysis and details of canonical functions}

Auxiliary tables were organized according to the strength of each variable and ordered by the respective cross-loadings, permitting an evaluation of three columns:

1. Standardized coefficient or coefficient with which the variable enters the construction of the canonical function. The mathematical formulation of the function can be seen below the charts. The higher the value (with no sign), the greater the role of the original variable in the new variable that has been created (canonical function).

2. Canonical loadings are measurements that evaluate the contribution of the variable in the composition of the new variable. Again, the higher the value, the greater the strength of the variable in the new variable. 
3. Cross-loadings are measurements that assess how much the new variable can explain the original variable. The higher this value is (in module) the better it explains the composition. Values lower than 0.7 were considered weak. Therefore, they carry less weight in the analytical evaluation of the canonical function and the correlation that was found.

Evaluating the canonical coefficient, the canonical loadings and the cross-loadings, many of the original variables were seen to have a standardized coefficient and/or low canonical loadings and/or cross-loadings. From these results, the following analysis concentrated only on the variables that were best described in each canonical function.

With the results that were obtained and considering the latent variables in the auxiliary tables, the existence of a correlation was found between the set of dependent and independent variables. However, this correlation, in addition to being stronger in strategic practices and the support system, is more intense in some of the variables that compose it. This is perhaps the major contribution of this study. Although the hypothesis is true, the correlation occurs more strongly in only some original variables.

In the correlation with the support system, the sub-variables that make up the new independent variable (strategic practices) and have canonic loadings (from 0.768 to 0.899 ) and high cross-loadings (from 0.873 to 0.746 ), with coherent standardized coefficients are six in number, as follows: (a) definition of indicators to monitor and evaluate the achievement of environmental goals and targets; (b) the occurrence of regular meetings to map the strong and weak points identified in the environmental management system; (c) an analysis of threats and opportunities in relation to stakeholders; (d) consideration given in the strategic planning of the company to investment for research and development in the field of environmental management; (e) analysis of environmental management as a benefit for creating a competitive advantage; and (f) inclusion of changes and reviews in environmental legislation when setting the company's goals and targets.

Other empirical considerations that were analyzed regarding strategic practices do not have any strong canonical loadings in the composition of the independent variable. These include the opinion of interested parties and initiatives linked to certification and financing agents. In accordance with Adams et al. (2011), the weak representation of these practices could be related to managers' personal values and are not put into practice into company daily life when they face dilemmas during decision making. Concerning stakeholders in general, it may be that the companies under study do not value consumers' strength, for instance, when it comes to environmental factors in their purchase decisions (Kang, 2011), which seem to be so strong in more developed countries (Arora \& Cason, 1995; Christmann, 2004; Henriques \& Sadorsky, 1996; Simon, 1992). The correlation is coherent, for example, in that the independent variable inclusion of information on the public image of the company concerning the environment in the definition of goals and targets of the organization does not have strong enough canonical weight, canonical loadings and cross-loadings to constitute a new independent variable.

As for certification agencies, and also competitors with certification, this finding can be explained by the low rate of companies in the sample that have obtained environmental certification. In the descriptive analysis, approximately $86 \%$ of the companies under study had no ISO 14001 certification and only 56\% publish their actions in social reports or Global Reporting Initiative. This corroborates the study by Alperstedt, Quintella, Martignago and Bulgacov (2013) that identified a lack of ISO 14001certification in ceramics companies due to the fact that their clients had their own checklists and did not require the companies to obtain certification.

The strongest correlation, which was found between strategic practices and support systems, was to be expected. According to Chia and Rasche (2010), strategic practices are the result of the knowledge of strategic decision-makers and involve analysis, planning and action to achieve goals; in this case related to the natural environment. However, with the focus on policies and managerial actions, although these practices have to do with what managers actually do with their rational choices, the complexity of environmental management often stops these planned actions from becoming effective in practice. On other occasions, these supposed practices are little more than discourse. Kavinski, Souza-Lima and Maciel-Lima (2013) noted that although companies consider environmental issues in their strategies and 
plan actions for this purpose, their major concern is profit and dividends for their shareholders. As a result, investing in green design or in the main processes may only be important after they have achieved their main goals.

In the case of product design (DVI), which has the lowest correlation among the variables that compose the praxis, in environmental management, the adoption of reverse logistics, which includes return actions, recycling, reuse and reprocessing for the composition of products, is the weakest original sub-variable. This suggests the companies have to make a greater effort, since Law 12.305 (Lei $\mathrm{n}$. $12.305,2010)$ requires deadlines to be met by companies and they should consider this in their strategic policies and practices. It is understood that these actions require considerable effort on the part of companies.

Concentrating on the strongest correlation, in the group of dependent variables (DV3) of the Support System, nine sub-variables stood out with high canonical loadings (greater than 0.783) and cross-loadings (greater than 0.774), suggesting that they have a strong influence on the construction of the canonical variable and indicating that they are well represented. They are: (a) general analysis of the environmental policy implemented paving the way for future developments; (b) definition of priority for areas that represent an environmental risk; (c) use of indicators to monitor the implementation of the environmental management system; (d) regular analysis to define continuing improvements in the environmental management system; (e) consideration of environmental risks as a result of the operations of the company when shaping its environmental policy; (f) use of indicators for issuing a general report on environmental management in line with the company's policy; (g) adoption of a plan to raise the awareness of collaborators regarding the importance of environmental management; (h) existence of a structured publicity plan to announce the environmental actions to internal and external opinion formers; (i) procedures to verify the effectiveness of corrective actions within the company.

The set of original dependent variables that were excluded during the formation of the new variable (praxis) relative to the support system included the following variables: (a) the existence of someone responsible for the process of periodically checking and reviewing environmental aspects and impacts; (b) the development of activities to raise the awareness of collaborators in the creation and innovation of cleaner processes; (c) appropriate training for collaborators to operate the environmental management system; (d) regular reviewing of environmental legislation applicable to the company's products and services; and (e) regular checks of reports of non-compliance in order to implement preventive and corrective actions. But the weights of these activities do not deserve to be highlighted in the interpretation of the new variable, either because of the low standardized coefficient or canonical and cross loadings of little relevance.

Coelho, Coelho and Godoy (2013) call attention to the efficient communication of attitudes, stances and performance for interested parties as a requirement for increasing a company's competitive advantage. In the case of the created variable, although a structured communication plan to reveal environmental actions to internal and external opinion makers should be considered, in reality internal education and training to operate the environmental management system are weakly represented in the construction of a new canonical variable. This is an indication that they are not well represented in the correlation. Numerous studies, such as that by Aragón-Correa, Martín-Tapia and Hurtado-Torres (2013), have shown the positive and significant relationship between the practices of sharing information with collaborators and the development of strategic environmental actions by companies, showing that sharing can make a significant contribution to the rational and discursive strategic practices implemented by companies.

\section{Discussion and Conclusions}

This article sought to analyze environmental management in Brazilian industrial companies from the concept of strategy as practice. For this purpose, the pertinent aspects were analyzed in the literature 
on environmental management in order to identify the variables that make up this construct, translated into this article as strategic praxis. The literature on strategy as practice provided the theoretical arguments on praxis and strategic practice, enabling an understanding of the practices involved in environmental management as the convergence of the flow of activities in terms of the decisions made and the policies adopted by organizations; i.e., rational, discursive and episodic practices. Meanwhile, praxis was understood from the viewpoint of effectively implemented environmental management. In this sense, the study was conducted for the purpose of breaking away from the dichotomy of planning and action or the strategic and the operational (Simpson \& Samson, 2010).

To provide support, a quantitative study was conducted in which a number of Brazilian companies participated. The 225 questionnaires received were submitted to Canonical Correlation multivariate analysis. The data confirmed the hypothesis of a correlation between the companies' strategic practices and their praxis (environmental management). However, the correlation best represents the original variables at the support system level, valuing the correlation that was found. The strength of the correlation is reduced when it is associated with the main processes and becomes weaker still when associated with product design. Even in relation to the support system, not all the original variables came to make up the canonical variable, such as training for employees, suggesting new conclusions.

Specifically speaking, it could be claimed that companies' praxis when associated with their strategic practices is more focused on analysis systems, monitoring and evaluation of risks, and less focused on actions concerning the main processes and product design. In the conception of praxis, the correlation does not imply changes in the companies' operation systems, which might mean a difference between discourse and action. As discursive, rational and episodic practices do not appear to be strongly linked to the efforts employed, for instance to eliminate pollutants and dangerous materials from products, or reverse logistics, reuse and recycling, it has to be admitted that environmental management is still not being treated from a strategic viewpoint by the companies in this study.

This does not mean that no action is taken to this end, but there is a gap between planning and policies and the action that is actually taken. These finding are especially important when considering the conclusions of Simpson and Samson (2010), to whom the gap that separates strategic intentions and operational actions does not help to maintain or improve companies environmental performance. On this matter, Teixeira, Jabbour, Oliveira, Battistelle and Castro (2011) point out that when a company is forced to implement environmental initiatives to comply with external requirements, it tends to adopt reactive practices that do not lead to ongoing improvements in products and processes. Consequently, environmental management tends to result in increasingly reactive stances, with policies being adopted to meet only the minimum external requirements and demands.

This study makes some important contributions to the theme. In particular, this study provided: (a) a view of environmental management and strategic practices from a more complex conceptual structure; (b) an analysis of the theme from a view of strategy as practice, which has hitherto not been included in the literature on environmental management, at least within this perspective; (c) a joint analysis of conception and implementation of the environmental strategy of companies, breaking away from the dichotomy cited by Simpson and Samson (2010); (d) the use of a multivariate canonical correlation analysis that enabled the correlation of a set of dependent and a set of independent variables; (e) the generation of new variables from a canonical correlation, enabling new conclusions to be reached. The latter contribution in particular offers a very complex view of the problem, revealing the possibility of various compositions of correlations that could be altered in different contexts, samples of companies and moments in time.

The information discussed in this study is derived from quantitative research and, therefore, does not permit an individual analysis of the companies. Likewise, the study focused only on medium-sized and large companies in the context of a Brazilian state. Given these limitations, it is important that future studies should use other methodological approaches and focus on other contexts and other types of organization. 


\section{Acknowledgments}

The authors thank the Brazilian Council for Scientific Development and Technology (CNPq) for financial support.

\section{References}

Acselrad, H. (2004). Apresentação: de "bota foras" e "zonas de sacrifício" - um panorama dos conflitos ambientais no Estado do Rio de Janeiro. In H. Acselrad (Org.), Conflito social e meio ambiente no estado do Rio de Janeiro (pp. 7-18). Rio de Janeiro: Relume Dumará.

Adams, R. B., Licht, A. N., \& Sagiv, L. (2011). Shareholders and stakeholders: how do directors decide? Strategic Management Journal, 32(12), 1331-1355. doi: 10.1002/smj.940

Alfred, A. M., \& Adam, R. F. (2009). Green management matters regardless. Academy of Management Perspectives, 23(3), 17-26. doi: 10.5465/AMP.2009.43479261

Alperstedt, G. D., Quintella, R. H., Martignago, G., \& Bulgacov, S. (2013). A atuação no mercado externo influencia a estratégia de gestão ambiental das empresas brasileiras? Um estudo multicaso na indústria cerâmica de Santa Catarina. Revista de Gestão Social e Ambiental, 7(2), 3-19. doi: $10.5773 /$ rgsa.v7i2.726

Aragón-Correa, J. A., Hurtado-Torres, N., Sharma, S., \& Garcia-Morales, V. J. (2008). Environmental strategy and performance in small firms: a resource-based perspective. Journal of Environmental Management, 86(1), 88-103. doi: 10.1016/j.jenvman.2006.11.022

Aragón-Correa, J. A., Martín-Tapia, I., \& Hurtado-Torres, N. (2013). Proactive environmental strategies and employee inclusion: the positive effects of information sharing and promoting collaboration and the influence of uncertainty. Sage Publications Organization \& Environment, 26(2), 139161. doi: $10.1177 / 1086026613489034$

Aragón-Correa, J. A., Matías-Reche, F., \& Senise-Barrio, M. E. (2004). Managerial discretion and corporate commitment to the natural environment. Journal of Business Research, 57(9), 964-975. doi: 10.1016/S0148-2963(02)00500-3

Arora, S., \& Cason, T. N. (1995). An experiment in voluntary environmental regulation: participation in EPA'S 33/50 Program. Journal of Environmental Economics and Management, 28(3), 271286. doi:10.1006/jeem.1995.1018

Banerjee, S. B. (2001). Managerial perceptions of corporate environmentalism: interpretations from industry and strategic implications for organizations. Journal of Management Studies, 38(4), 489513. doi: 10.1111/1467-6486.00246

Barbieri, J. C. (2006). Gestão ambiental empresarial: conceitos, modelos e instrumentos. São Paulo: Saraiva.

Bonilla, S. H., Almeida, C. M. V. B., Giannetti, B. F., \& Huisingh, D. (2010). The roles of cleaner production in the sustainable development of modern societies: an introduction to this special issue. Journal of Cleaner Production, 18(1), 1-5. Retrieved from http://www.advancesincleanerproduction.net/papers/journals/2010/2010_jcp_cleanprod.pdf. doi: 10.1016/j.jclepro.2009.09.001

Brown, H. S., Vergragt, P. J., \& Cohen, M. J. (2013). Societal innovation in a constrained world: theoretical and empirical perspectives. In M. J. Cohen, H. S Brown, \& P. J. Vergragt (Eds.), 
Innovations in sustainable consumption: new economics, socio-technical transitions and social practices (Chap. 1, pp. 1-27). Cheltenham, UK: Edward Elgar Pub. doi: $10.4337 / 9781781001349.00009$

Chia, R., \& Rasche, A. (2010). Epistemological alternatives for researching strategy as practice: building and dwelling worldviews. In D. Golsorkhi, L. Rouleau, D. Seidl, \& E. Vaara (Eds.), The Cambridge handbook on strategy as practice (pp. 23-33). Cambridge, UK: Cambridge University Press.

Child, J., \& Tsai, T. (2005). The dynamic between firms' environmental strategies and institutional constraints in emerging economies: evidence from China and Taiwan. Journal of Management Studies, 42(1), 95-125. doi: 10.1111/j.1467-6486.2005.00490.x

Christmann, P. (2000). Effects of best practices of environmental management on cost advantage: the role of complementary assets. Academy of Management Journal, 43(4), 663-680. doi: $10.2307 / 1556360$

Christmann, P. (2004). Multinational companies and the natural environment: determinants of global environmental policy standartisation. Academy of Management Journal, 47(5), 747-760. doi: $10.2307 / 20159616$

Christimann, P., \& Taylor, G. (2001). Globalization and the environmental: determinant of firm selfregulation in China. Journal of International Business Studies, 32(3), 439-458. doi: $10.2139 /$ ssrn. 277452

Coelho, A. L. A. L. de, Coelho, C., \& Godoi, C. K. (2013). O discurso da sustentabilidade e sua inserção no contexto organizacional. Revista Gestão \& Conexões, 2(1), 147-186. Retrieved from http://www.periodicos.ufes.br/ppgadm/article/view/5061/4361. doi: 10.13071/regec.23175087.2013.2.1.5061.147-186

Copeland, B. R. (2008). The pollution haven hypothesis. In K. P. Gallagher (Ed.), Handbook on trade and the environment (pp. 49-59). Cheltenham, UK: Edward Elgar Pub.

Cordano, M., \& Frieze, I. H. (2000). Pollution reduction preferences of U.S. environmental managers: applying Ajzen's theory of planned behavior. Academy of Management Journal, 43(4), 627-641. doi: $10.2307 / 1556358$

Coyle, J. J., Thomchick, E. A., \& Ruamsook, K. (2015). Environmentally sustainable supply chain management: an evolutionary framework. In L. Robinson Jr. (Ed.), Marketing dynamism \& sustainability: things change, things stay the same... (pp. 365-374). New York: Springer International Publishing. doi: 10.1007/978-3-319-10912-1_129

Donnelly, K., Beckett-Furnell, Z., Traeger, S., Okrasinski, T., \& Holman, S. (2006). Eco-design implemented through a product-based environmental management system. Journal of Cleaner Production, 14(15), 1357-1367. doi: 10.1016/j.jclepro.2005.11.029

Emirbayer, M., \& Mische, A. (1998). What is agency? American Journal of Sociology, 103(4), 9621023. Retrieved from http://www.ssc.wisc.edu/ emirbaye/Mustafa_Emirbayer/ARTICLES_files/what\%20is\%20agen cy.pdf

Forza, C. (2002). Survey research in operations management: a process based perspective. International Journal of Operations \& Production Management, 22(2), 152-194. doi: $10.1108 / 01443570210414310$

Gerner, S., Kobeissi, A., David, B., Binder, Z., \& Descotes-Genon, B. (2005). Integrated approach for disassembly processes generation and recycling evaluation of an end-of-life product. 
International Journal of Production Research, 43(1), 195-222. doi: $10.1080 / 00207540412331270414$

Hair, J. F., Jr., Black, W. C., Babin, B. J., Anderson, R. R., \& Tatham, R. L. (2009). Análise multivariada de dados. Porto Alegre, RS: Bookman.

Handfield, R., Walton, S. V., Sroufe, R., \& Melnyk, S. A. (2002). Applying environmental criteria to supplier assessment: a study in the application of the analytical hierarchy process. European Journal of Operational Research, 141(1), 70-87. doi: 10.1016/S0377-2217(01)00261-2

Hart, S. L. (1995). A natural-resource-based view of the firm. Academy of Management Review, 20(4), 986-1014. doi: 10.5465/AMR.1995.9512280033

Hart, S. L., \& Dowell, G. (2011). A natural resource based view of the firm: 15 years after. Journal of Management, 37(5), 1464-1479. doi: 10.1177/0149206310390219

Henriques, I., \& Sadorsky, P. (1996). The determinants of an environmentally responsive firm: an empirical approach. Journal of Environmental Economics and Management, 30(3), 381-395. doi: 10.1006/jeem.1996.0026

Henriques, I., \& Sadorsky, P. (1999). The relationship between environmental commitment and managerial perceptions of stakeholder importance. Academy of Management Journal, 42(1), 8799. doi: $10.2307 / 256876$

Hettige, H., Hug, M., Pargal, S., \& Wheeler, D. (1996). Determinants of pollution abatement in developing countries: evidence from South and Southeast Asia. World Development, 24(12), 1891-1904. doi: 10.1016/S0305-750X(96)00076-9

Hrdlicka, H. (2009). As boas práticas de gestão ambiental e a influência do desempenho exportador: um estudo sobre as grandes empresas exportadoras brasileiras (Tese de doutorado). Faculdade de Economia, Administração e Contabilidade, Universidade de São Paulo, São Paulo, SP, Brasil.

Hrdlicka, H., \& Kruglianskas, I. (2010). Influência das práticas de gestão socioambiental na internacionalização de empresas brasileiras. In A. Fleury (Org.), Gestão empresarial para a internacionalização das empresas brasileiras (Vol. 1, pp. 253-289). São Paulo: Atlas.

Humphreys, P. K., Wong, Y. K., \& Chan, F. T. S. (2003). Integrating environmental criteria into the supplier selection process. Journal of Materials Processing Technology, 138(1/3), 349-356. doi: 10.1016/S0924-0136(03)00097-9

Jabbour, C. J. C., Teixeira, A. A., Jabbour, A. B. L. S. de, \& Freitas, W. R. S. de (2012). "Verdes e competitivas?": a influência da gestão ambiental no desempenho operacional de empresas brasileiras. Ambiente \& Sociedade, 15(2), 151-172. Retrieved from http://www.scielo.br/pdf/asoc/v15n2/09.pdf. doi: 10.1590/S1414-753X2012000200009

James, P. (1994). Business environmental performance measurement. Business Strategy and the Environment, 3(2), 59-67. doi: 10.1002/bse.3280030208

Jarzabkowski, P. (2005). Strategy as practice: an activity based approach. London: Sage.

Jarzabkowski, P., \& Balogun, J. (2009). The practice and process of delivering integration through strategic planning. Journal of Management Studies, 46(8), 1255-1288. doi: 10.1111/j.14676486.2009.00853.x

Jarzabkowski, P., Balogun, J., \& Seidl, D. (2007). Strategizing the challenges of a practice perspective. Human Relations, 60(1), 5-27. doi: 10.1177/0018726707075703 
Jarzabkowski, P., \& Spee, A. P. (2009). Strategy-as-practice: a review and future directions for the field. International Journal of Management Reviews, 11(1), 69-95. doi: 10.1111/j.14682370.2008.00250.x

Johnson, G., Melin, L., \& Whittington, R. (2003). Guest editors' introduction - Micro strategy and strategizing: towards an activity-based view. Journal of Management Studies, 40(1), 3-22. doi: 10.1111/1467-6486.t01-2-00002

Kang, Y. (2011). Adoption of environmental management strategy for manufacturing: an integration of institutional forces and strategic behavior approach. International Journal of Business Research, 11(4), 74-88.

Kanji, G. K. (2008). Architecture of business excellence in the public and service sectors. Total Quality Management \& Business Excellence, 19(4), 399-415. doi: 10.1080/14783360801987779

Kavinski, H., Souza-Lima, J. E., \& Maciel-Lima, S. (2013). O discurso da sustentabilidade nas organizações: um estudo multicaso de grandes empresas. Revista Brasileira de Ciências Ambientais, 27, 2176-9478. $\quad$ Retrieved from https://www.yumpu.com/pt/document/fullscreen/51943509/edicao-27-marco-13-rbciamb

Klassen, R. D., \& McLaughlin, C. P. (1996). The impact of environmental management on firm performance. Management Science, 42(8), 1199-1214. doi: 10.1287/mnsc.42.8.1199

Kolk, A., \& Mauser, A. (2002). The evolution of environmental management: from stage models to performance evaluation. Business Strategy and the Environment, 11(1), 14-31. doi: $10.1002 /$ bse. 316

Lei n. 12.305, de 02 de agosto de 2010. (2010). Institui a Política Nacional de Resíduos Sólidos; altera a Lei n o 9.605, de 12 de fevereiro de 1998; e dá outras providências. Diário Oficial da União. Brasília, DF. Retrieved from http://www.planalto.gov.br/ccivil_03/_ato20072010/2010/lei/112305.htm

Maas, S., Schuster, T., \& Hartmann, E. (2014). Pollution prevention and service stewardship strategies in the third-party logistics industry: effects on firm differentiation and the moderating role of environmental communication. Business Strategy and the Environment, 23(1), 38-55. doi: $10.1002 /$ bse. 1759

Majumdar, S. K., \& Marcus, A. A. (2001). Rules verses discretion: the productivity consequences of flexible regulation. Academy of Management Journal, 44(1), 170-179. doi: 10.2307/3069344

Montabon, J., Sroufe, R., \& Narasimhan, R. (2007). An examination of corporate reporting environmental management and firm performance. Journal of Operations Management, 25(5), 998-1014. doi: 10.1016/j.jom.2006.10.003

Nehrt, C. (1998). Maintainability of first mover advantages when environmental regulations differ between countries. Academy of Management Review, 23(1), 77-97. doi: 10.5465/AMR.1998.192962

Newton, T., \& Harte, G. (1997). Green business: technicist kitsch? Journal of Management Studies, 34(1), 75-98. doi: 10.1111/1467-6486.00043

Pedroso, A., Cella-de-Oliveira, F. A., Dutra, I. S., \& Morozini, J. F. (2012). Processo ou ações de ecoeficiência em empresas da cadeia produtiva agroindustrial da suinocultura de Toledo - Paraná, Brasil. Capital Científico, 10(1), 1-17. Retrieved from http://revistas.unicentro.br/index.php/capitalcientifico/article/view/1945/1724 
Peng, M. W., Wang, D. Y. L., \& Jiang, Y. (2008). An institutional-based view of international business strategy: a focus on emerging economies. Journal of International Business Studies, 39(5), 920936. doi: $10.1057 /$ palgrave.jibs. 8400377

Perez-Valls, M., Cespedes-Lorente, J., \& Moreno-Garcia, J. (2015). Green practices and organizational design as sources of strategic flexibility and performance. Business Strategy and the Environment. doi: $10.1002 / b s e .1881$

Porter, M. E. (1985). Competitive advantage: creating and sustaining superior performance. New York: The Free Press.

Porter, M. E., \& Linde, C. van der (1995). Green and competitive: ending the stalemate. Harvard Business Review, 28(6), 120-134. doi: 10.1016/0024-6301(95)99997-E

Scott, W. R. (2001). Institutions and organizations (2nd ed.). London: Sage Publications.

Sharma, S. (2000). Managerial interpretations and organizational context as predictors of corporate choice of environmental strategy. Academy of Management Journal, 43(4), 681-697. doi: $10.2307 / 1556361$

Shih, L. H. (2003). Greening the supply chain in international corporations. International Green Productivity Association, 5(3), 20-23.

Shrivastava, P. (1995). Environmental technologies and competitive advantage [Summer Special Issue]. Strategic Management Journal, 16, 183-200. doi: 10.1002/smj.4250160923

Simon, F. (1992). Marketing green products in the triad. Columbia Journal of World Business, 27(3/4), 268-285.

Simpson, D., \& Samsom, D. (2010). Environmental strategy and low waste operations: exploring complementarities. Business Strategy and the Environment, 19(2), 104-118. doi: 10.1002/bse.626

Sroufe, R., Montabon, F., Narasimhan, R., \& Wang, X. (2002). Environmental management practices: a framework. Greener Management International, (40), 23-44. doi: 10.9774/GLEAF.3062.2002.wi.00004

Surjono, D. W. (2011). A sustainable production and consumption and the role of cleaner production. International Journal of Academic Research, 3(4), 176-179.

Teixeira, A. A., Jabbour, C. J. C., Oliveira, J. H. C., Battistelle, R. A. G., \& Castro, R. (2011). Environmental practices and motivational elements: a study of leading Brazilian companies. Environmental Quality Management, 21(1), 39-51. doi: 10.1002/tqem.20307

Uehara, T. H., Otero, G. G. P., Martins, E. G. A., Philippi, A., Jr., \& Mantovani, W. (2010). Pesquisas em gestão ambiental: análise de sua evolução na universidade de São Paulo. Ambiente \& Sociedade, 13(1), 165-185.

Walter, S. A., \& Augusto, P. O. M. (2012). Prática estratégica e strategizing: mapeamento dos delineamentos metodológicos empregados em estratégia como prática. Revista Eletrônica de Ciência Administrativa, 11(1), 131-142. doi: 10.5329/RECADM.20121101008

Whittington, R. (1996). Strategy as practice. Long Range Planning, 29(5), 731-735. doi: 10.1016/00246301(96)00068-4

Whittington, R. (2003). The work of strategizing and organizing: for a practice perspective. Strategic Organization, l(1), 117-125. doi: 10.1177/1476127003001001221 
Whittington, R. (2006). Completing the practice turn in strategy research. Organization Studies, 27(5), 613-634. doi: 10.1177/0170840606064101

Yang, C. C., Yang, K. J., \& Peng, S. Y. (2011). Exploration strategies and key activities for system of environmental management. Total Quality Management, 22(11), 1179-1194. doi: $10.1080 / 14783363.2011 .603201$

\section{Authors' Profiles}

Graziela Dias Alperstedt

Rua Dr. Armínio Tavares, 111, 88015-250, Florianópolis, SC, Brazil. E-mail address: graziela.esag@ gmail.com

Sergio Bulgacov

Av. 9 de Julho, 2029, Bela Vista, 01313-902, São Paulo, SP, Brazil. E-mail: sergio.bulgacov@gmail.com 